Images in...

\title{
Urinary tuberculosis associated to adalimumab
}

\author{
Celia Coelho Henriques, ${ }^{1}$ Mónica Sousa, ${ }^{1}$ Begoña Lopéz, ${ }_{1}^{1}$ Adelaide Milheiro, ${ }^{2}$ Nuno Riso ${ }^{1}$ \\ ${ }^{1}$ Department of Internal Medicine 2, Curry Cabral Hospital, Lisbon, Lisbon, Portugal; \\ ${ }^{2}$ Department of Pathological anatomy, Hospital Curry Cabral, Lisbon, Portugal
}

Correspondence to Dr Celia Coelho Henriques, celia.c.henriques@gmail.com

\section{DESCRIPTION}

The authors report a case of a 52-year-old male with rheumatoid arthritis first diagnosed 30 years ago who had a partial response to multiple therapies with diseasemodifying agents. He was started on a tumour necrosis factor- $\alpha$ (TNF- $\alpha$ ) antagonist, adalimumab 40 mg every 2 weeks with progressive improvement of articular manifestations. He remained in the remission criteria range for about 3 years. Before beginning anti-TNF- $\alpha$ treatment he had a negative screening for mycobacterial infection or latent disease. The patient presented with a 6-months history of weight loss, asthenia and malaise. There was no
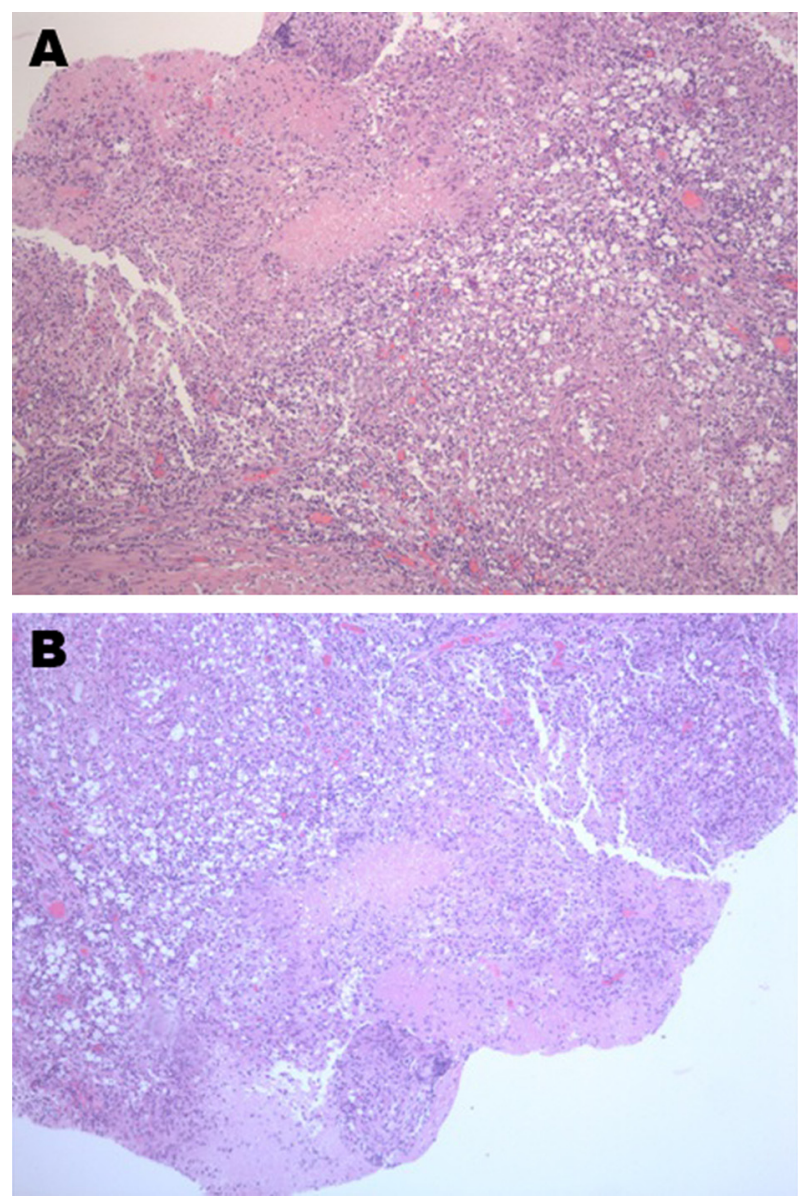

Figure 1 (A, B) Erosion of the entire epithelium. Intense lymphohistiocytic infiltrate. Epithelioid granulomas with central necrosis, non-caseous. associated history of fever or night sweats. He also had persistent dysuria and haematuria non-responding to multiple antibacterial drug regimens. Physical examination was unremarkable. Laboratory findings showed a normal renal function, elevated inflammatory parameters (erythrocyte sedimentation rate of $38 \mathrm{~mm} / \mathrm{h}$ and serum $\mathrm{C}$ reactive protein was $3-2 \mathrm{mg} / \mathrm{dl}$ ), normocytic, normochromic anaemia (haemoglobin of $12.6 \mathrm{~g} / \mathrm{dl}$ ) and the urine analysis revealed presence of proteins, leucocytes and erythrocytes. Blood and urine bacteriological tests were negative for aerobic and anaerobic organisms. The direct search for Mycobacterium was negative. All diagnostic imaging exams (renal and bladder ultrasound and abdominal CT) were normal. Cystoscopy showed only inflammation and bladder biopsy performed to exclude a neoplastic process revealed non-caseous granulomatosis (figures 1 and 2). Six urine cultures for acid-fast bacilli were performed, with a positive result 4 weeks later. The patient started antituberculous drug treatment with complete resolution of symptoms. The overall incidence of serious infections associated with anti-TNF- $\alpha$ therapy has been estimated at 6.3 per 100 patient-years with adalimumab. ${ }^{1}$ In most patients, tuberculosis represents reactivation of a previous infection. Diagnosing mycobacterial disease in patients treated with biologic agents is not always linear as they often present with extrapulmonary disease, generally as paucibacillary infections. In these cases, confirmation of the diagnosis is usually by culture. ${ }^{2}$ To our knowledge, this is the first case reporting urinary tuberculosis in a

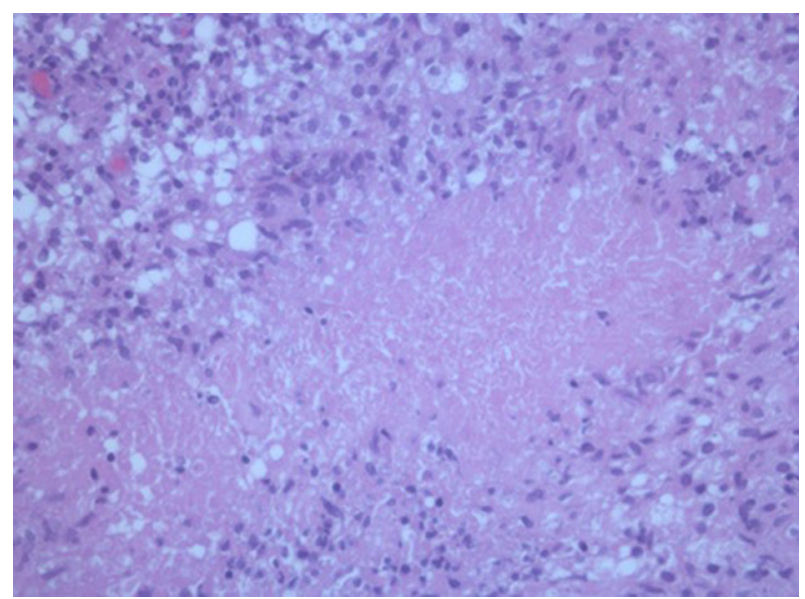

Figure 2 Amplified 100x - Epithelioid granulomas with central necrosis, non-caseous. 


\section{BMJ Case Reports}

rheumatoid arthritis patient after 3 years of treatment with adalimumab.

\section{Learning points}

- Mycobacterial disease is a major cause of infection in patients treated with TNF- $\alpha$ antagonists.

- The diagnosis of urinary tuberculosis is difficult because its symptoms are non-specific.

- Screening has lowered the incidence of anti-TNFassociated tuberculosis, however the continuous monitoring of opportunistic infections should not be forgotten.
Competing interests None.

Patient consent Obtained.

\section{REFERENCES}

1. Koo S, Marty FM, Baden LR. Infectious complications associated with immunomodulating biologic agents. Hematol Oncol Clin North Am 2011:25:117-38.

2. van Ingen J, Boeree MJ, Dekhuijzen PN, et al. Mycobacterial disease in patients with rheumatic disease. Nat Clin Pract Rheumatol 2008;4:649-56.

This pdf has been created automatically from the final edited text and images.

Copyright 2012 BMJ Publishing Group. All rights reserved. For permission to reuse any of this content visit http://group.bmj.com/group/rights-licensing/permissions.

BMJ Case Report Fellows may re-use this article for personal use and teaching without any further permission.

Please cite this article as follows (you will need to access the article online to obtain the date of publication).

Henriques CC, Sousa M, Lopéz B, Milheiro A, Riso N. Urinary tuberculosis associated to adalimumab. BMJ Case Reports 2012; 10.1136/bcr.11.2011.5247, Published XXX

Become a Fellow of BMJ Case Reports today and you can:

- Submit as many cases as you like

- Enjoy fast sympathetic peer review and rapid publication of accepted articles

- Access all the published articles

Re-use any of the published material for personal use and teaching without further permission

For information on Institutional Fellowships contact consortiasales@bmjgroup.com

Visit casereports.bmj.com for more articles like this and to become a Fellow

Keep up to date with all published cases by signing up for an alert (all we need is your email address) http://casereports.bmj.com/cgi/alerts/etoc 